\title{
Tomasz Tylec
}

Cracow University of Economics

e-mail: tylect@uek.krakow.pl

ORCID: 0000-0002-2998-3720

\section{THE BEIJING CONSENSUS - THE CHINESE DEVELOPMENT MODEL \\ KONSENSUS PEKIŃSKI - CHIŃSKI MODEL ROZWOJU}

DOI: $10.15611 / \mathrm{pn} .2019 .8 .12$

JEL Classification: O2, P4

Summary: The article attempts to present the essence and main assumptions of the concept of China's socio-economic policy in opposition to the concept of economic policy defined by the principles of Washington Consensus. The Beijing Consensus is a set of principles characterizing the economic policy implemented by the Communist Party of China since the late 1970s, resulting in the intensification of the country's economic growth and development, while maintaining the specificity of the political system and taking into account China's socio-economic conditions. China, recognizing that the country faces a unique set of challenges and therefore requires unique solutions, has chosen its own alternative development concept. The socio-economic policy implemented according to certain principles, meets not only social needs, but also becomes an increasingly noticeable way to implement Chinese soft power on the international stage. By making this choice, China remains on its own path of rapid development and unprecedented increase in political and economic significance in the global economy.

Keywords: China, Beijing Consensus, socio-economic policy.

Streszczenie: W artykule podjęto próbę przedstawienia istoty, w tym głównych założeń, chińskiej polityki społeczno-gospodarczej w odniesieniu do koncepcji polityki gospodarczej określonej w zasadach tzw. konsensusu waszyngtońskiego. Konsensus pekiński stanowi zbiór zasad charakteryzujących politykę gospodarczą realizowaną przez Komunistyczną Partię Chin od końca lat 70., skutkującą intensyfikacją wzrostu i rozwoju gospodarczego kraju, przy jednoczesnym zachowaniu specyfiki systemu politycznego oraz uwzględnieniu uwarunkowań społeczno-gospodarczych Chin. Strategia ta - realizowana według określonych zasad - nie tylko wychodzi naprzeciw potrzebom społecznym, ale staje się także coraz bardziej zauważalnym sposobem na realizację chińskiego soft power na arenie międzynarodowej. Dokonując tego wyboru, Chiny pozostają na własnej ścieżce szybkiego rozwoju i bezprecedensowego wzrostu znaczenia politycznego i gospodarczego w światowej gospodarce.

Słowa kluczowe: Chiny, konsensus pekiński, polityka społeczno-gospodarcza. 


\section{Introduction}

The dynamic growth and economic development of China has attracted attention of scientists and politicians, and sparked a discussion about the reasons for such spectacular success. In order to emphasize the difference and uniqueness of the Chinese leadership's approach to the socio-economic transformation under the implemented economic development policy, it has been defined in the literature of the subject by the separate concept of the so-called Beijing Consensus.

In this model, on the one hand, there is a stable and strong authority and with iron consistency enforcing the adopted development strategy, a strong authority that also decides about the scope of use of market mechanisms and the process of opening markets as part of the phenomenon of globalization, and on the other, flexibly orienting towards stable development, different from the 'shocking' ideas proposed by Western institutions [Ramo 2004, p. 2].

For this reason, the Chinese path of development is opposed to the economic and political neoliberal model proposed to developing countries by international financial institutions, expressed in the principles of the so-called Washington Consensus. More and more often, China is perceived not only as a successful case of economic development, but also as a model for other developing countries.

The aim of the study is to present the Chinese approach to socio-economic changes in China's development policy implemented for almost four decades. In connection with the above, a thesis was adopted stating that there are premise that allow to conclude that the approach based on the political concept expressed in the Chinese Communist Party's (CCP) economic policy, called the Beijing Consensus, may provide the effective achievement of strategic goals in the process of economic development and be a model for other developing countries.

\section{Essence and genesis of the Beijing Consensus}

Since its inception, the People's Republic of China (PRC) implementing its own development policy, commonly known as the Beijing consensus, has been far from the neoliberal economic policy promoted by institutions such as the World Bank and the International Monetary Fund and the United States Department of Commerce. Instead, China sought to implement a policy whereby the "state" acted as the supreme guide, coordinator and factor of change, using pragmatically the experience of the successful development of Japan, South Korea, Taiwan and Singapore [Mathews, Tan 2015, pp. 147-148]. At the same time, it has been noted that at the initial stage of reforms the Chinese reformers did not know in what direction they were heading. Therefore the dominating feature was the imitation and search for sensible patterns that would allow limiting the problems of the functioning of the then planned Chinese economy. In addition, it is noted that the reformers themselves did not 
believe that their governments could correct imperfections and sufficiently influence the course of the economic processes [Naughton 2007, p. 86].

Supporters of the Beijing Consensus assume that some solid attributes touted as key in this approach, such as financial support for strategic sectors, restrictions on private sector development, and strict political control were permanent determinants of economic growth. However, bearing in mind the detailed solutions, two fundamental periods and reform models are distinguished as part of China's economic policy.

The first period, namely the 1980 s, is characterized by the implementation of a policy based on many activities fully consistent with the idea of the Washington Consensus, which include private entrepreneurship, financial reforms and to some extent political liberalism. It can therefore be argued that the assumptions of the Washington Consensus, at least in terms of the direction of the changes made, make it possible to explain the economic success achieved to a greater extent.

In actual fact, in the 1990s, China departed from such a policy model in favour of more static solutions, referred to as the Beijing Consensus. This model was based on greater financial and political control and favouring state-owned enterprises at the expense of private enterprises (for more see [Huang 2010]).

With strong supervision and control of the state, Beijing has developed a hybrid form of capitalism, consisting in limited openness of the economy to external competition, simultaneous strong government control of strategic sectors, support of the most dynamically developing domestic enterprises (market leaders), ensuring the appropriate level of investment from state resources and focusing the banking sector on supporting the best enterprises (national 'champions') [Kurlantzick 2013].

There are two elements of Chinese reforms that almost everyone can agree on. First, the 'market' has proved to be the overriding way of organizing business processes. Almost every element in the Chinese transformation process related to accelerating growth was associated with opening markets and increasing the level of competition. China's opening of markets to join the World Trade Organization (WTO) towards the end of 2001 led to a further acceleration of growth. The Chinese experience has shown that markets have functioned and constituted the core of development activities. Secondly, the Chinese experience does not provide arguments for 'market fundamentalism'. In other words, there are no reasons to treat the market as a superior instrument in the entire Chinese reform process, requiring full and rapid implementation in all possible areas of socio-economic life. In contrast, the continuous expansion of human potential, a coherent and predictable system of incentives and property rights, as well as governmental coordination to reduce market failure have proved to be as important as market expansion [Naughton 2007, p. 7].

Both the process of state control and the gradual opening up to market reforms were carried out calmly and with caution, which did not correspond to the recommendations of the IMF and the World Bank, which include: rapid privatization, deregulation, unilateral liberalization of trade and investment under 
strict conditions (i.e. 'shock therapy'). In contrast, the Chinese reformers saw the enormity of the unmet needs within their own society and economy, which prompted them to reduce barriers and gradually open their own economic system, while creating the conditions for society to allow entrepreneurial attitudes as an element based on which became possible to meet existing market demand. Foreign enterprises were allowed to operate freely within special economic zones to increase investment value and force technology transfer to Chinese enterprises. Such a policy was considered to contribute to growth, while at the same time, it did not threaten the Chinese government's loss of economic governance and management [Naughton 2007, p. 87].

\section{Key recommendations arising from the Beijing Consensus}

The Beijing Consensus, unlike the recommendations made under the Washington Consensus, is considered a set of loose guidelines implemented by the Chinese authorities. Nevertheless, the literature on the subject contains a list of certain features characterizing the economic policy pursued. Xin Li, Kjeld Erik Brødsgaard and Michael Jacobsen present a set of general characteristics of the rules referred to as the Beijing Consensus. They include the following ten principles of the Beijing Consensus [Li, Brødsgaard, Jacobsen 2009, pp. 8-21].

1. Avoiding 'blind' copying of solutions. The basis for this position was the conviction that due to the different level of development and structure of a given economy, as well as specific socio-cultural conditions, it is not possible to directly use a textbook set of theories and experiences of other countries. Awareness in this area was already revealed in 1956 in Mao Tse-Tung's political document ("On Ten Great Relationships") [Tse-Tsung 1956]. It was created to warn its own party against uncritical adaptation of the Stalinist model without taking into account the specificity of the conditions of Chinese society and economy. Thus, foundations were created for autonomy and for building a socio-economic reform policy based on own principles. M. Tse-Tung's successors, such as Deng Xiaoping, already at the beginning of their reform implementation began to reject plans to massively adapt the principles imposed by Western culture (westernization) and firmly adhered to the principles of choosing a development strategy corresponding to the real needs and conditions of the Chinese economy. At the same time, they avoided the disastrous errors arising from shock therapy reforms proposed by the West to the countries of Central and Eastern Europe (CEE) and the former Soviet Union (USSR). His political successors, Jiang Zemin and Hu Jintao, were equally consistent in this matter. Thus, despite focusing reforms on the market economy, the Chinese socio-economic system has always had its own distinctiveness and specificity.

2. The combination of market and planning. Under this assumption, no extreme ideology, be it in the form of fully free market capitalism or communal planned economy, was accepted by the Chinese decision makers. The first system fails because 
of information asymmetry, and the second because of problems related to economic calculation. The solution is to find in the existing conditions a balance between these two extremes adapted to the existing socio-economic constraints and the level of economic development.

In the case of the PRC, one of the key factors for the success of market reforms and the opening of the economy is the appropriate sequence of actions and highlighting the goal of the liberalization and stimulation of competition. Imports of investments and technologies have become important, but with the right level of protection for key strategic industries, such as the financial sector and agriculture.

3. Flexibility in the operation and use of funds. The basis of this principle was the belief that Western economic theories and the policy based on them are developed and based on different conditions of developed markets. Therefore, even if the general course of action set for transforming the economies of developing countries based on these theories coincides with them, detailed guidelines, such as the pace of transformation or convergence, will be much more complex than the ideas and expectations of Western theorists. For this reason, reforms should be planned gradually and implemented flexibly. Bearing in mind the so-called Washington Consensus shock therapy implemented in the CEE-4 countries and in the former USSR bloc, China has chosen the evolutionary path for their implementation. Under this approach, the gradual implementation of reforms has proved to be the right way to maintain stability and avoid the risk of failure.

4. Recognition of the supremacy of the right to implement one's own policy. Chinese leaders consistently maintain the opinion that each nation is free to choose its own strategy and policy regarding the construction of the economy in accordance with existing socio-economic conditions. The justification of this thesis is the fact that in the 1990s most of the reforms based on the Washington Consensus carried out in the CEE and the former USSR countries did not bring the expected results [for more see Economic Growth..., 2005]. The above principle is also reflected in the CCP's political assumptions about peaceful coexistence, equality, respect for the social system, sovereignty and independence. This is even more justified because the strong argument for the right to pursue one's own policy or freedom is that modern developed countries such as Great Britain, France, the USA, Germany, Japan and recently industrialized economies like South Korea, Singapore, Hong Kong and Taiwan have enjoyed it throughout the history of industrialization [Wade 2004].

5. Political stability. The Chinese authorities remained aware that political stability, both internal and external, is a prerequisite for economic development. Unlike Western theorists and the recommendations of the Washington Consensus, Chinese policy makers understood the dynamics of the relationship between political stability and economic development well and were aware that these two areas are essentially interdependent and, moreover, interact with each other and limit themselves. At this point, the shock therapy implemented in the CEE and the former USSR 
(in accordance with the guidelines of the Washington Consensus) is once again cited as a negative example of reforms, where political reforms were carried out first.

6. Self-reliance. In the programs and statements of the Chinese leaders, one can find numerous references to the importance of diligence and independence. Mao Tse-Tsung emphasized that only people are the source of material wealth creation, technology development and social progress, which was also reflected in the policy of 'relying primarily on self'. The history of China allows to prove the importance of both independence and learning skills from others.

7. Continuous improvement of industry. The Chinese authorities were aware of the importance of actions aimed at modernizing the industrial sector, as well as the fact that in the event of a development lag, one cannot leave everything to the market mechanism. This particularly concerned strategic sectors requiring significant capital expenditure (capital-intensive), knowledge-intensive or high-tech industries. Moreover, state supervision over strategic sectors was kept, which included: the arms industry, banking, petrochemical industry, telecommunications, civil aviation, production and distribution of electricity and shipbuilding.

8. Activities for domestic innovative activity. As part of the development concept, China has adopted a strategy to invest in education and technology. Despite the fact that the economy originally used to rely more on the import and transfer of technology, it was also realized that the key to the country's development and the ability to cope with competition in a rapidly changing global market is to develop its own innovation potential. China has begun to develop its national innovation system, ultimately trying to move from a centrally controlled system to a system based on a network of innovative enterprises. To this end, they used a number of innovative and at the same time adapted to the social specificity instruments to stimulate domestic innovations.

9. Careful and prudent liberalization in the sphere of finance. China acted extremely cautiously also when it began to liberalize the financial market. On the one hand, the reason for this caution is the possible lack of experience in managing a highly specific financial market, and on the other, the fear of losing control over strategic national assets. However, it should be considered as crucial that China's leaders were and are aware of the huge risk of sudden liberalization (the actions of speculators and the financial crises caused by them: Latin American in the 1980s and 1990s, the 1997 Asian crisis, the Russian crisis in 1998). For Chinese leaders, the main culprit in global crises was blind faith in the free market.

10. Growth aimed at achieving social harmony. The concept of building a harmonious society appeared already at the birth of New China in 1949. At that time, in the thoughts of Mao Tse-Tung, the concept of creating society was advanced through the absence of persecution and exploitation, and the belief that through a cultural revolution one could find a way to move "from chaos to full harmony", and despite the fact that the principle of striving for social "harmony was mentioned last, in fact it seems to be the most important, indicating the most important goal of 
reforms and development activities. Moreover, Chinese leaders have never abandoned this concept and did not stop pursuing its materialization: the construction of a prosperous, democratic and civilized socialist state.

\section{An outline of the current status}

The reforms implemented since 1978 have generally brought positive results. They have enabled economic development unprecedented in world history and enabled China to join the global economy and benefit from the flow of capital and the growing importance of global exports. As a result of reforms undertaken nationwide, the quality of life has improved, as evidenced by increasingly better indicators in the HDI ranking. This indicator increased from 0.43 in 1980 to 0.752 in 2017 [Rosner 2019]. Gross Domestic Product per capita (purchasing power parity international dollars, current prices), GDP rose from \$ 309.588 in 1980 to \$ 18116.045 in 2018 [World... 2019]. At the same time, life expectancy increased from 67.77 in 1981 to 76.34 in 2015 and the number of higher education students, per 100,000 increased, from 326 in 1990 to 2,576 in 2017 [China... 2019].

The Chinese development model also has its weaknesses. The Chinese economy in the last thirty years has developed mainly on the basis of exports and investments, ${ }^{1}$ at the expense of internal consumption, which began to be a burden due to the saturation of Chinese products on the global market and thus a reduction in foreign demand.

The global crisis of 2008 forced a reorientation and development based on the internal market. To this end, actions aimed at stimulating consumption and investment in infrastructure were launched, while at the same time facilitating access to credit, and supporting technically advanced sectors, including R\&D. Due to the enormous pollution of the environment, emphasis was placed on the development of clean energy sources. Such actions, strongly focused on supporting innovation, can ultimately, in a specific Chinese centrally controlled system, become the basis for further growth and economic development.

Many goals have not yet been achieved, such as the introduction of the full convertibility of the yuan and making the yuan a reserve international currency. Similarly to the Japanese strategy, China began the pursuit of developed countries

1 The growing imbalance in trade and the increasingly stronger position of China, and thus D. Trump's actions aimed at strengthening and protecting his own economy have resulted in the initiation of a trade war between China and the US by imposing duties on an increasing number of products, including among others, intellectual property rights. The intensification of this troublesome conflict for markets is causing numerous fears about global economic growth. It is estimated that global GDP would be $0.6 \%$ lower in 2021 if the market slumps during an all-out trade war, compared to a no trade war scenario, i.e. the equivalent of a $\$ 1.2$ trillion hit to the global economy [Hanson, Orlik 2019]. Simultaneously, Moody's Analytics estimates that the Trump administration's trade war with China has resulted in 300,000 fewer jobs being created in the U.S. [Layne 2019]. 
by lowering the exchange rate of its own currency, which was to stimulate exports, as well as from the intensive development of education and stimulation of a high level of savings in the economy. A cheap currency, low wages and low prices of raw materials allowed to create a competitive advantage of Chinese producers. Despite the Chinese authorities' awareness that it is not possible, at least for now, to replace the dollar with yuan, China is systematically seeking to make the yuan a reserve international currency. A necessary condition for the internationalization of the yuan is its full convertibility. At the beginning of the current decade, China gave up the administrative determination of the yuan exchange rate and agreed to gradually release its currency. The goal of this new monetary policy is to accelerate the process of turning the yuan into a global currency, and ultimately to dethrone the US dollar. It should be added that an important step in the process of internationalization of the yuan was its inclusion in the JDR basket in 2016, which was the first change in the basket's composition since 1999 (when the euro replaced the DEM and FRF). Nevertheless, the general tendency seems to be clear - both due to the growing importance of China in the global economy and the economic policy activities undertaken by the Chinese authorities that the yuan should gradually become an increasingly important element of the global monetary and financial system, and the Chinese economy - a key element of the global economy.

The strength of the institutions of the Chinese financial institutions is reflected in the fact that Chinese banks in 2014 emerged from the crisis of 2008 victoriously and were in the top ten of the global financial giants. According to the $S \& P$ Global Market Intelligence ranking, in 2017 at the top of the list of the largest banks in the world in terms of assets were four Chinese banks: Industrial \& Commercial Bank of China (4.0 bln USD), China Construction Bank (3.4 bln USD), Agricultural Bank of China (3.24 bln USD) and Bank of China (2.99 bln USD) [Ranking... 2019]. At the same time, it is noted that the actual condition of Chinese banks is much worse than officially reported. It is argued that the position of Chinese banks is due to the increasing indebtedness of Chinese companies and households. The growth of these debts can be a sign of impending problems related to excessive debt management. Since 2013, the 12 largest Chinese banks, each with assets greater than USD 500 billion, have increased their total balance by almost $40 \%$. During the same period, six of the largest American banks increased their balance sheets by only $7 \%$. At the same time, the combined balance sheets of the five largest UK banks shrank by $21 \%$. It is also noteworthy that the supply of loans granted by large Chinese banks is growing four times faster than by American banks. The average ROA of Chinese banks is $1.16 \%$ and American ones $1.32 \%$. This may indicate a lesser problem of credit quality. In 2017, the six largest Chinese banks lost USD 76.8 billion due to bad credit, while six US banks only USD 19.4 billion [Gadomski 2019]. 


\section{Conclusions}

Since the beginning of the process of political and economic reforms, China has remained on its own path of rapid development and an unprecedented increase in political and economic importance in the global economy. An important basis for these changes was the consistent implementation of the actions referred to in the Western literature as the Beijing Consensus. This strongly politically and culturally conditioned process takes into account the specificity not only of China itself, but also of a broadly understood group of countries developing in a way different from that imposed by the Washington Consensus. Based on the arguments cited, the statement can be made that the Beijing Consensus is an alternative development concept, especially in relation to the set of neoliberal recommendations of the Washington Consensus or the Post-Washington Consensus, which also includes the importance of cultural conditions and efficient institutional infrastructure as well as the importance of human capital and the flow of information. The Chinese path of development is based on the principle that each country faces a unique set of challenges and therefore requires unique solutions.

Considering the above, it should be noted that the Beijing Consensus must be looked at a bit broader. This consists not only in an effective model of economic development, but also - or above all - a new model of cooperation that China offers to developing countries. In relations with foreign countries, it is based on the so-called pancha shila rule (five principles of peaceful coexistence: no intervention in the internal affairs of other states, respect for sovereignty and territorial integrity, no aggression, peaceful coexistence, equality and mutual benefits) and unconditional financial assistance. Activity in these dimensions is visible in many areas, among others: in various international forums (e.g. as part of the ASEAN + 3 structure or the Shanghai Cooperation Organization), in activities undertaken in African countries and in the initiative to establish the Asian Investment Bank Infrastructural (AIIB). Preferential loans and credit lines granted mainly for the implementation of infrastructure projects, not conditional on the implementation of reforms in line with Beijing's expectations, staff training by Chinese specialists in conjunction with the policy of "non-interference" and respect for the political system of the given country effectively speaks to developing countries. Thus, it discredits and hinders the activity of the IMF, the World Bank, the OECD and the EU, whose development assistance depends on progress in such matters as respect for human rights, democratization and the implementation of free market economy principles.

To sum up, it should be recognized that the Beijing Consensus is a kind of challenge to the existing international order. It is particularly strong considering the fact that China's political stability based on meritocracy is an example that in the modern world authoritarianism can function and be a lasting model of government even in the event of accelerated modernization, transformation and integration with the global economy. 


\section{Bibliography}

China Statistical Yearbook, China Statistical Press, http://www.stats.gov.cn/tjsj/ndsj/2018/indexeh.htm (15.10.2019).

Economic Growth in the 1990s: Learning from a Decade of Reform, 2005, World Bank, Washington D.C. Gadomski W., Chińskie banki na czele, ale z kłopotami, aleBank.pl, https://alebank.pl/chinskie-bankina-czele-ale-z-klopotami/ (15.10.2019).

Hanson D., Orlik T., All-Out Trade War Could Cost Global Economy \$1.2 Trillion, 5.08.2019, https:// www.bloomberg.com/news/articles/2019-08-05/all-out-trade-war-could-cost-global-economy-12-trillion-chart (15.10.2019).

Huang Y., 2010, Debating China's economic growth: The Beijing consensus or The Washington consensus, Academy of Management Journal.

Kurlantzick J., 2013, China's model of development and the Beijing consensus, China-US Focus, 29 April.

Layne R., Trump trade war with China has cost 300,000 U.S. jobs, Moody's estimates, www.cbsnews. com, 12.09.2019, https://www.cbsnews.com/news/trumps-trade-war-squashed-an-estimated300000-jobs-so-far-moodys-estimates/ (15.10.2019).

Li X., Brødsgaard K.E., Jacobsen M., 2009, Redefining Beijing Consensus: Ten general principles, Copenhagen Discussion Papers, no. 29.

Mathews J.A., Tan H., 2015, China's Renewable Energy Revolution, Palgrave Macmillan, London and New York.

Naughton B., 2007, The Chinese Economy: Transitions and Growth, Cambridge, London.

Ramo J.C., 2004, The Beijing Consensus: Notes on the New Physics of Chinese Power, Foreign Policy, London.

Ranking the world's 100 largest banks, S\&P Global Market Intelligence, https:/www.spglobal.com/ marketintelligence/en/news-insights/trending/t-38wta5twjgrrqcef4_ca2 (15.10.2019).

Rosner M., Human Development Index (HDI), https://ourworldindata.org/human-development-index (10.10.2019).

Tse-Tsung M., 1956, On the ten major relationships, 25 April, https://www.marxists.org/reference/ archive/mao/selected-works/volume-5/mswv5_51.htm (dostęp: 14.09.2017).

Wade R., 2004, Introduction to the 2003 Paperback Edition: Creating Capitalism, [in:] R. Wade (ed.), Governing the Market: Economic Theory and the Role of Government in East Asian Industrialization, Princeton University Press, Princeton.

World Economic Outlook Database, IMF, https://www.imf.org/external/pubs/ft/weo/2019/02/weodata/ index.aspx (15.10.2019). 